\title{
Research on the Cultivation Mechanism of Students' Practical Ability in Engineering Cost
}

\author{
Fangyan $\mathrm{Yu}^{1, \mathrm{a}}$, Yanping $\mathrm{Xu}^{1, \mathrm{~b}}$ and Minhang Qiu ${ }^{1, \mathrm{c}}$ \\ ${ }^{1}$ School of Engineering Management, Nanchang Institute of Technology, Nanchang, Jiangxi, China \\ ayufangyan@nut.edu.cn, ${ }^{b} x u y a n p i n g @ n u t . e d u . c n,{ }^{c}$ qiuminhang@nut.edu.cn
}

\begin{abstract}
The engineering cost specialty is one of the hottest newly added by the Ministry of Education according to the needs of national economic and social development. It is based on economics, management science and civil engineering, and has developed from the architectural engineering management profession subject. Due to the large amount of content involved in the engineering cost profession, students have higher requirements when they are studying the major. They not only require students to master the corresponding theoretical basis of engineering cost, but also the practical ability of students at this stage. New requirements were put forward. Based on this, based on the research results of Zhang Yan, Zhang Jianhua, Shi Lei, Li Bo and other scholars, this paper explores how to cultivate the teaching reform of engineering cost professionals based on practical ability.
\end{abstract}

Keywords: teaching, practice ability, engineering cost

\section{INTRODUCTION}

Architectural related majors have always been the key specialty of current universities. Engineering cost is an important part of the architectural profession. The professional features are combined with engineering technology and economics. As a student of engineering cost, if you want to effectively master the knowledge in the profession, you need to learn from the engineering practice. For example, the calculation of the foundation pit in the project cost and the calculation of the beam in the beam need to have rich engineering experience and ability to accurately determine the amount of work[1].

China's economic system has been further deepened. In the field of basic engineering construction, engineering cost personnel play a pivotal role, and the market urgently needs a large number of engineering cost professionals. However, today's supply is far less than the demand, and the current engineering cost graduates' ability is far from the level required by the market. In order to meet the needs of the current market for engineering cost talents, improve the professional level of engineering cost graduates, let students become truly high-skilled applied talents, make professional operations more adapt to the requirements of international development for high-quality applied talents, deep level Exploring teaching reform is imperative.

The engineering cost specialty originated in the West and played a very active role in the development of the modern construction industry. There are many related disciplines involved, such as management, engineering, law, etc., which are comprehensive. The main teaching purpose of the discipline is to cultivate composite construction talents for engineering construction, cost management and project decision-making. With the continuous development of modern building technology, the actual requirements for such talents are getting higher and higher. Therefore, doing a good job in teaching cost engineering has a very positive significance for promoting the development of the construction industry. In the current stage of engineering cost professional teaching process, the biggest problem is that its practical teaching level is relatively low, which seriously hinders the cultivation of compound talents at this stage. Therefore, only by doing the corresponding teaching reform work can we continue Improve the practical teaching level of engineering cost. The author believes that in order to improve the practical teaching level of engineering cost professionally, it is only necessary to do professional teaching, professional skills, and comprehensive practice at all stages to continuously improve the overall quality of practical teaching[3].

\section{PROBLEMS IN THE PRACTICAL TEACHING OF ENGINEERING COST SPECIALTY}

\subsection{Practice Teaching Activities Monotonous}

In the process of teaching, teachers are accustomed to placing emphasis on the theoretical knowledge, while ignoring the cultivation of students' practical ability. In the long run, students' ability to analyze and solve problems cannot be developed. In addition, teachers also tend to separate theoretical knowledge from practical teaching into a dual structure teaching, which is not only not conducive to understanding all aspects of knowledge, but also not conducive to students' flexible use of knowledge[5].

Today's forms of practical teaching activities are limited to case analysis and practical hand operations. There is a lack of examination of students' resilience. When faced with problems, students may lack experience in dealing with them, and the level of graduates is far from the requirements of employers. 


\subsection{The Teaching System is not Perfect}

The practical characteristics of this course determine that it is not enough to improve students' comprehensive ability by explaining cases in class. Classroom teaching must be combined with extracurricular practice. Nowadays, the lack of teaching venues and infrastructure makes the students of engineering costing students lack the opportunity of actual training. As a result, their practical ability is weak and their confidence in actual operation is not strong. It is difficult to call them high-quality professionals.

\subsection{The "Dormant" Phenomenon of the Off- campus Training Base is More Serious.}

Most of the established off-campus training bases (or schoolenterprise cooperation or self-construction) are unsustainable due to lack of support for supporting management and maintenance funds, or imperfect school policies, resulting in "signing only, no action, only The problem of reconstruction and non-reuse is low, and the utilization rate of the training base is low, which makes the off-campus training bases exist in name only. Some bases have not used them effectively since they signed the cooperation agreement. According to the survey, nearly half of the off-campus training bases currently do not operate reasonably, resulting in a serious waste of resources outside the off-campus training base.

\subsection{Schools are not Strict with the Supervision of Student Practice}

In the practical teaching of engineering cost, the lack of teacher supervision is also an important reason for the low efficiency of practical teaching. In the process of practice, students will encounter many problems and require students to use their knowledge for in-depth research and exploration. Many students have fear and luck. After a few problems, they choose to withdraw and give up. Because teachers lack supervision, it is difficult to find such problems, which will cause students to gain less in practice. As this problem continues, students' interest in practical learning will gradually decrease, and the vitality of practical teaching will also be affected[2]

\section{THOUGHTS ON THE ESTABLISHMENT OF TRAINING MECHANISM FOR PRACTICAL ABILITY OF ENGINEERING COST STUDENTS}

\subsection{Increase Investment in Practical Teaching Staff}

In the process of the development of engineering cost in colleges and universities, in order to realize the cultivation of students' practical ability in the true sense, we should first increase the investment in the practical teaching staff. Through the practical teaching of rich teachers to participate in the actual teaching process, and disseminate its good practical experience, based on this, based on the continuous improvement of students' practical ability. In this process, the school can hire some senior engineers with long-term work and rich practical experience and high theoretical literacy as the lecturer of practical teaching, which can not only ease the teaching pressure of teachers, but also to a large extent. Improve students' specific understanding of the work they will do in the future. In addition, teachers can also lead students to actually enter the actual project construction, and personally carry out relevant engineering construction practice activities, continuously deepen the connection between practice and theory, deepen their understanding of engineering cost practice teaching, and strive to improve Students' own level of practice.

\subsection{School-enterprise Cooperation to Continuously Improve Students' Practical Ability Level}

At this stage, many majors in colleges and universities appear in the form of school-enterprise cooperation, which not only can cultivate more modern new-type talents for enterprises, but also continuously improve students' comprehensive practical ability through the combination of school and enterprise, and realize modern talents. The cultivation has a very positive effect. Therefore, in the actual teaching process of engineering cost professional, it is also possible to improve the students' ability level through the combination of school and enterprise. In addition, in the actual teaching process, the engineering cost specialty should also realize the open school, and cultivate more and more engineering cost talents through the platform of school-enterprise cooperation[5].

\subsection{Strengthen the Reform of Teaching Methods}

The curriculum plan should adopt targeted measures. It should be based on the requirements of professional personnel training and the basic quality of professional talents. The classroom teaching, production practice, social engineering practice and other extracurricular practice activities and research and other teaching links are organically combined to balance students' superior innovative thinking ability and comprehensive quality.

The teaching reform of engineering cost should focus on the construction of professional core curriculum. Textbook reform is the focus of professional core curriculum reform. Our requirements for new textbooks are theoretically concise and concise, meeting the requirements of professional knowledge; let the teaching materials follow the actual situation of the society, according to industry standards, according to "project orientation, task decomposition" Organize the content of teaching materials and emphasize the actual operation; in addition, carry out case teaching, add more thinking and inspiring engineering case content in the book, optimize the course content, make full use of existing resources, and better achieve professional training objectives; The syllabus is closely related to the changes of social trends, meets the needs of contemporary talent standards, pays more attention to the proportion of theoretical knowledge and practical knowledge, and improves the pertinence, continuity 
and integrity of actual CAS. Timely supplement the relevant documents and regulations of the local engineering cost authorities, update the engineering quantity calculation rules, pay attention to the adjustment of the relevant national rates, so that the course content is always advanced and in line with the society[2].

\subsection{Make Full Use of School Resources}

In the course of engineering cost professional practice teaching, the engineering design drawings and structure are two very important points.

Therefore, colleges and universities should continuously improve and update the drawings and structure database of engineering cost professional, and the paper version Drawings and other documents are made for the students of engineering cost to find and read. At the same time, the electronic drawing search port should be established in the school website. Students can view these drawings through the network, which can provide more for their practical teaching convenient way. For example, teachers can ask a question before the start of practical teaching, let students solve their own problems in practice teaching, improve their hands-on and innovation ability, and also allow them to view and budget electronic drawings. Take them to the construction site of the actual road project, let them find and find problems, and solve them, so that their practical ability can be quickly improved[4].

\subsection{Establish a Reasonable Set of Off-campus Practice Teaching System}

In order to do a good job in the construction and operation of the off-campus practice teaching base of engineering cost, it is necessary to establish a reasonable off-campus training system. For the teaching work of engineering cost engineering in colleges and universities, it is necessary to cultivate the engineering cost professional talents as the goal, and to rationalize the teaching curriculum and class hours of the off-campus practice teaching base for the curriculum arrangement of engineering cost professional students, to ensure that students have sufficient off-campus practice. Experience and improve the professional ability of engineering cost students. By establishing a reasonable offcampus practice teaching system, students can fully guarantee the practice activities outside the school, improve students' interest in engineering cost, and effectively improve students' social practice ability. For colleges and universities, in order to better improve the off-campus practice activities, you can choose the method of off-campus recruitment to recruit some engineering and technical personnel with rich practical experience to carry out teaching work, and improve students' professional ability in engineering cost. Create a double-teacher team to comprehensively improve the instructor's practical training ability, effectively make up for the deficiencies in the school's teachers' practical ability, and improve the quality of practical teaching[4].

\subsection{Improve the Practical Teaching Evaluation System}

The traditional practice teaching evaluation focuses on the summary evaluation and ignores the formative evaluation. It is only the students' knowledge reserve ability rather than the knowledge application ability. Future practical teaching evaluation should be a process-based dynamic evaluation, focusing on individual differences and innovative abilities of students. The traditional practice teaching evaluation is based on teachers. The evaluation of future practical teaching should be completed by teachers and students, especially the self-evaluation of students. The evaluation of the on-campus training course is completed by the instructor and the students. In the assessment process of the team's innovation practice, students can also join the process of mutual evaluation. The evaluation of off-campus practice activities consists of a practical teaching evaluation team composed of practical instructors in the school and internship personnel in the construction enterprise to conduct a comprehensive evaluation. Students should complete a detailed internship summary report after the completion of the practical teaching activities, except for the internship summary report. It is also necessary to provide relevant information during the internship period, such as photos, videos, news reports, etc., and report to the intern students and the practical teaching evaluation team at the internship summary meeting held by the school, mainly to explain their internship situation and experience. Tell me what I have learned in my internship, how satisfied I am with my internship, where I think I am not doing well, and so on. Evaluation is for reflection. With reflection and practice teaching, students will continue to progress. Students participate in evaluation to recognize their own advantages and disadvantages, absorb information that is instructive for their own growth, learn self-reflection and self-education, and maximize development

\section{SUMMARY}

In summary, in the process of cultivating engineering cost talents in colleges and universities, although the teaching level has been significantly improved at this stage, there are still relatively large defects in the cultivation of practical ability of talents. With the continuous development of China's modern construction industry, the requirements for engineering cost talents are getting higher and higher. Only in the actual teaching process, colleges and universities should pay more attention to the practical teaching of engineering cost, and combine the current construction engineering to cost talents. The specific needs of the students to cultivate their practical ability, based on this, to provide more complex talents for related companies.

\section{REFERENCES}

[1] Zhang Yan. Reflections on the Teaching Reform of Engineering Cost Based on the Cultivation of Practical Ability. Science and Wealth. 2018, Issue 12

[2] Zhang Jianhua. Teaching Reform Practice of Engineering Cost Specialty. Global Market Information Review. 2018. 
[3] Shi Lei. Thoughts on the construction of off-campus practice teaching base for engineering cost. Management Manager. 2016-11.

[4] Li Bo. Discussion on the reform of engineering cost professional teaching under the background of practical ability training. Education and Teaching Forum. 2018, 17. 